\title{
Polimeroetan oinarritutako fabrikazio gehigarria eta 3D inprimaketa: etorkizuneko teknologia gaur egungo gizartean
}

\author{
Additive manufacturing and 3D printing in polymers: \\ future technology in current society
}

\author{
Cristian Mendes ${ }^{1}$, Beñat Artetxe ${ }^{* 2}$, Leire Ruiz-Rubio ${ }^{1,2}$, Jose Luis Vilas ${ }^{1,2}$ \\ ${ }^{1}$ BCMaterials, Basque Center for Materials, Applications and Nanostructures. \\ UPV/EHU Zientzia Parkea \\ ${ }^{2}$ Zientzia eta Teknologia Fakultatea. Euskal Herriko Unibertsitatea, UPV/EHU
}

LABURPENA: Fabrikazio gehigarriak, metodo tradizionalekin alderatuta, abantaila ugari ditu, hala nola diseinu askatasuna, pertsonalizazioa, egitura konplexuak fabrikatzeko gaitasuna edota prototipoen sorrera azkarra. 3D inprimaketa teknologietan material ezberdin ugari erabiltzen badira ere, polimeroak dira gailentzen direnak, haien aldakortasuna, kostu baxua eta propietate fisiko-kimikoak direla eta. Horrela, artikulu honek polimeroetan oinarritutako fabrikazio gehigarrirako metodoak eta horietan erabiltzen diren polimero nagusiak laburbiltzen ditu, baita zenbait arlotan dituzten erabilera-esparruak ere: biomedikuntzan, elektronikan eta ingeniaritza aeroespazialean.

HITZ GAKOAK: fabrikazio gehigarria, 3D inprimaketa, polimeroak, termoegonkorrak, termoplastikoak.

ABSTRACT: Additive manufacturing in comparison to traditional fabrication methods displays numerous advantages such as freedom of design, mass customization, the ability to manufacture complex structures or the rapid creation of prototypes. Although there are many materials used in the $3 D$ printing technologies, polymers are the most prominent due to their versatility, low cost and suitable physico-chemical properties. Thus, this article gives an overview of $3 D$ printing technologies applied to polymeric materials, the main polymers used, as well as their applications in fields like biomedicine, electronics and aerospace engineering.

KEYWORDS: Additive Manufacturing, 3D printing, polymer, thermosets, thermoplastics.

\footnotetext{
* Harremanetan jartzeko / Corresponding author: Beñat Artetxe Arretxe, Kimika Ezorganikoa Saila, Zientzia eta Teknologia Fakultatea, UPV/EHU, Sarriena auzoa z/g 48940, Leioa, Bizkaia, Euskal Herria. - benat.artetxe@ehu.eus - https://orcid.org/0000-0002-7373-4596.

Nola aipatu / How to cite: Mendes, Cristian; Artetxe, Beñat; Ruiz-Rubio, Leire; Vilas, Jose Luis (2019). "Polimeroetan oinarritutako fabrikazio gehigarria eta 3D inprimaketa: etorkizuneko teknologia gaur egungo gizartean»; Ekaia, ale berezia 2019, 101-119. (https://doi.org/10.1387/ekaia.19729).

Jasoa: 18 maiatza, 2018; Onartua: 18 uztaila, 2018.

ISSN 0214-9001 - eISSN 2444-3255 / (c) 2019 UPV/EHU
}

(c) (i) (2) Obra hau Creative Commons Atribución 4.0 Internacional-en lizentziapean dago 


\section{SARRERA}

Fabrikazio gehigarria (additive manufacturing, AM) teknologia ezberdinak biltzen dituen fabrikazio-prozesua da, gaur egun «3D inprimaketa» izenez ezagutzen dena. Prozesu horretan, objektu solidoa material jakin baten geruzak gainezarriz osatzen da. Teknika hau fabrikazio kengarriaren (mekanizazioa) kontrako prozesutzat hartzen da, azken honetan desira den produktua hasierako pieza batetik materiala erauziz lortzen baita [1].

Azken hogeita hamar urteotan zeharo aldatu da fabrikazio gehigarriaren garrantzia. Hasiera batean prototipo berriak sortzeko teknika bezala garatu bazen ere (rapid prototyping), urteak joan ahala jasandako hobekuntzen ondorioz, erreminten mundura hedatu da (rapid tooling). Gaur egun, ordea, kontsumitzaileentzat funtzionalak diren produktuak ekoiztean ardaztu du produkzioa (rapid manufacturing). Hain da handia teknologia honen eragina, ezen, adituek aurreikusten dutenez, urteko 200 eta 600 bilioi (amerikar) \$ bitarteko irabaziak sor baititzake etorkizunean [2]. «Industria iraultza»tzat identifikatu den honek gaur egungo merkataritzan aldaketa asko ekarriko ditu. Azken finean, erabiltzaile bakoitzak bere beharrak asetzen dituen produktu propioak sortzeko aukera izango du, merkatuko pieza berriak erosi beharrean.

Hasiera batetik, fabrikazio gehigarria merkatuaren eskariak betetzen saiatu da, metodo ezberdinen bidez pieza eta egitura konplexuak erdietsiz. Haren eragina, besteak beste, prozesuen energia-kontsumoaren eta xahutzen den material kantitatearen erredukzioan nabarmentzen da, edota produktuen pertsonalizazio eta eskuragarritasunean; bereziki ondoko eremuetan islatzen da: makina-industria, elektronika, medikuntza, ibilgailuak eta industria aeroespaziala (1. irudia) [3]. Ildo horretan, fabrikazio-sistema oztopoak gaindituz joan da, nahi diren tamainako piezak ekoitziz, fabrikazio-prozesuko akatsak baztertuz eta propietate mekanikoen hobekuntza sakona lortuz [4].

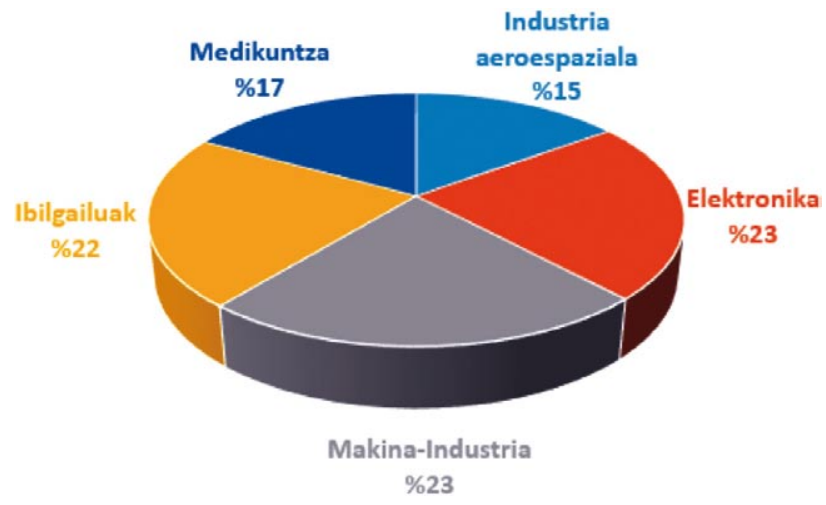

1. irudia. 2014az geroztik fabrikazio gehigarriaren aplikazio-esparru nagusiak. 
Ikerketa sakonaren emaitza diren fabrikazio gehigarrirako zenbait teknika garatu dira aspaldi honetan. Kasu guztietan, materiala patroi bidimentsional batean ezartzen da ( $x y$ planoa), eta jarraian, geruzaz geruza ( $z$ ardatzean zehar) hiru-dimentsioko egitura sortzen du. Lehenik eta behin, produktuaren diseinu birtuala gauzatzen da. Estrategia honen globalizazioak 3D egituren diseinurako zenbait software garatzea bultzatu du (CAD, SketchUp...), unibertsala den STL artxiboak irakurtzeko gai direnak. Hiru dimentsioko edozein objektu bi dimentsioko zenbait STL artxibotan banatu eta azter daiteke [5]. Nahiz eta mota bereko prozesuetan oinarritu, teknika desberdinen mekanismoek ez dute elkarrekin zerikusirik. Horrela, AEBtako «International Organization for Standardization (ISO)/American Society for Testing and Materials (ASTM) 52900:2015» erakundeak fabrikazio gehigarrirako teknikak zazpi multzo nagusitan banatu ditu [6]: injekzio aglutinatzailea (binder jetting), energia zuzenduaren deposizioa (direct energy deposition), estrusioa (material extrusion), injekzioa (material jetting), hauts-ohantzearen bidezko fusioa (powder bed fusion), xafla-ijezketa (sheet lamination) eta fotopolimerizazioa (vat photopolymerization). Materialak hauts-, hari-, xafla- edo likido-egoeran aurki daitezke. Kasu bakoitzean, tekniken deskribapena, ekoizle nagusiak eta erabiltzen diren material garrantzitsuenak 1. taulan laburbildu dira [7].

Injekzio aglutinatzailean, hauts-partikulak itsasgarri likido baten bidez selektiboki elkartzen dira. Teknika horren abantailen artean, inprimaketaren abiadura azkarra eta kostua nabarmen ditzakegu; gainera, material mota ugari erabil daitezke, zeramikoetatik edo metaletatik polimeroetara. Energia zuzenduaren deposizioan eta hauts-ohantzearen bidezko fusioan ere hauts egindako materialak erabiltzen dira, bereziki metalikoak. Teknika horietan aldiz, energia handiko laser bat zuzentzen da hautsera; geruza bakoitzean materiala puntuz puntu urtuta bukaerako pieza lortzen da. Lehen kasuan, hautsa korronte jarraitu bezala erabiltzen da; bigarrenean, berriz, geruzaz-geruza gehitzen eta urtzen da. Hots, geruza bat aglomeratu eta haren gainean material gehiago gehitzen da.

Estrusioan, hari erako materiala erabiltzen da, berotu eta pita batetik zehar presio konstantean pasarazten dena. Produktua, abiadura konstantean, substratu baten gainean solidotzen da. Aipatzekoak dira metodo honen azkartasuna, erraztasuna eta prezioa. Bestalde, xafla-ijezketan, itsasgarriz estalitako paperak, plastikoak edota xafla metalikoak bata bestearen gainean itsasten dira [8].

Fotopolimero likidoak bai fotopolimerizazioan, bai injekzioan erabiltzen dira. Lehen teknikan, argiak aktibatutako erreakzio baten bidez gauzatzen da ontzea. Bigarrenean, materialaren tanta likidoak substratu baten gainean jartzen dira; horiek solidotu eta dagokion objektuaren geruza sortzen da. Sarritan azken pausoan substratua deuseztatu egiten da. 
1. taula. Fabrikazio gehigarrirako prozesu garrantzitsuenak.

\begin{tabular}{|c|c|c|c|}
\hline Prozesua & Deskribapena & Ekoizleak & Materialak \\
\hline \multirow{3}{*}{$\begin{array}{c}\text { Injekzio } \\
\text { aglutinatzailea }\end{array}$} & \multirow{3}{*}{$\begin{array}{l}\text { Hautsak aglutinatzaile li- } \\
\text { kido batez selektiboki el- } \\
\text { kartzen dira. }\end{array}$} & Z-CORP & \multirow{3}{*}{$\begin{array}{l}\text { Hautsak: igeltsua, harea, } \\
\text { metalak, aleazioak eta ma- } \\
\text { terial konposatuak }\end{array}$} \\
\hline & & 3D Systems & \\
\hline & & ExONE & \\
\hline \multirow{2}{*}{$\begin{array}{c}\text { Energia } \\
\text { zuzenduaren } \\
\text { deposizioa }\end{array}$} & \multirow{2}{*}{$\begin{array}{l}\text { Gehitzen diren heinean } \\
\text { likidotzen dira materia- } \\
\text { lak energia termikoaren } \\
\text { bidez. }\end{array}$} & Trumpf & \multirow{2}{*}{$\begin{array}{l}\text { Metal hautsak (altzairuak, } \\
\mathrm{Co}, \mathrm{Al}, \mathrm{Cu}, \mathrm{Ti}, \mathrm{Ni} \text { ) eta ma- } \\
\text { terial konposatuak }\end{array}$} \\
\hline & & Optomec & \\
\hline Estrusioa & $\begin{array}{l}\text { Materiala zirrikitu edo } \\
\text { pita batetik igarotzen da. }\end{array}$ & Stratasys & $\begin{array}{l}\text { Polimero termoplastikoak: } \\
\text { ABS, ASA, poliamidak, } \\
\text { polikarbonatoak, polipro- } \\
\text { pilenoa }\end{array}$ \\
\hline \multirow{2}{*}{ Injekzioa } & \multirow{2}{*}{$\begin{array}{l}\text { Material tantak selekti- } \\
\text { boki gehitzen dira. }\end{array}$} & Stratasys & \multirow{2}{*}{$\begin{array}{l}\text { Zeramikoak, fotopolimero } \\
\text { likidoak, argizariak }\end{array}$} \\
\hline & & 3D Systems & \\
\hline \multirow{6}{*}{$\begin{array}{l}\text { Hauts-ohantzearen } \\
\text { bidezko fusioa }\end{array}$} & \multirow{6}{*}{$\begin{array}{l}\text { Hauts ohantzea selekti- } \\
\text { boki likidotzen da ener- } \\
\text { gia termikoaren bidez. }\end{array}$} & EOS & \multirow{6}{*}{$\begin{array}{l}\text { Metalak (Al, } \mathrm{Co}, \mathrm{Cr}, \mathrm{Ni} \text {, } \\
\text { Ti, altzairuak), polimeroak } \\
\text { (poliamidak, poliestirenoa, } \\
\text { poliaril-eter-zetonak) eta } \\
\text { polimero konpositeak }\end{array}$} \\
\hline & & 3D Systems & \\
\hline & & Renishaw & \\
\hline & & ReaLizer & \\
\hline & & ARCAM & \\
\hline & & Concept Laser & \\
\hline \multirow{2}{*}{ Xafla ijezketa } & \multirow{2}{*}{$\begin{array}{l}\text { Geruzak objektua era- } \\
\text { tzeko elkartzen dira. }\end{array}$} & MCOR & \multirow{2}{*}{$\begin{array}{l}\text { Papera eta konposite ter- } \\
\text { moplastikoak }\end{array}$} \\
\hline & & EnvisionTEC & \\
\hline Fotopolimerizazioa & $\begin{array}{l}\text { Fotopolimero likidoa ar- } \\
\text { giaren bitartez ontzen da. }\end{array}$ & 3D Systems & $\begin{array}{l}\text { Epoxi-erretxina eta erre- } \\
\text { txina akriliko nanoegitura- } \\
\text { tuak }\end{array}$ \\
\hline
\end{tabular}

ABS = akrilonitrilo-butadieno-estireno kopolimeroa; ASA = akriliko-estireno-akrilonitrilo kopolimeroa.

Nahiz eta zeramikoak eta metalak lantzeko teknologia gero eta garatuago egon, oraindik polimeroek zenbait abantaila aurkezten dituzte. Besteak beste, merkeagoak dira, moldakorragoak, errazagoa da haiekin lan egitea, eta forma, tamaina eta propietate fisiko-kimiko konplexu eta ezberdinak lortzeko konforma daitezke. Horregatik, lan honetan polimeroetan oinarritutako fabrikazio gehigarrirako teknikak eta hauen aplikazio nagusiak aurkezten dira. 


\section{POLIMEROETAN OINARRITUTAKO FABRIKAZIO GEHIGARRIRAKO METODOAK}

Aipatutako fabrikazio gehigarrirako zazpi prozeduren artean, teknologia ugari bereizten dira, «3D inprimaketarako teknika» izena dutenak [9]. Horietatik, polimeroetan oinarritzen direnen artean, zazpi garrantzitsuenak aztertuko ditugu hurrengo ataletan:

\subsection{Material-urtzearen bidezko modelatzea (F used Desposition Modelling, FDM)}

Stratasys Inc. konpainiako Scott Crumpek 1989an patentatutako teknika da material-urtzearen bidezko modelatzea (FDM). FDM teknologian oinarritzen diren inprimagailuek kontsumitzaileen artean ezagunenak izaten jarraitzen dute polimeroak inprimatzeko orduan. Estrusioan oinarritutako teknika honetan, diametro ezberdinetako polimero termoplastikozko (polikarbonatoa, akrilonitrilo-butadieno-estireno, azido polilaktikoa) bobinak erabiltzen dira, urtu eta pita betetik igaroarazten direnak. Azkenaldian, fusio-tenperatura altuagoko termoplastikoak ere (polieter-zetona bezalako polimero erdi-kristalinoak) erabil daitezke. 2. irudian erakusten den moduan, estrusio-prozesua jasan duen polimero erdilikidoa berehala solidotzen da, eta geruzaz geruza hiru dimentsioko objektua eratzen da.

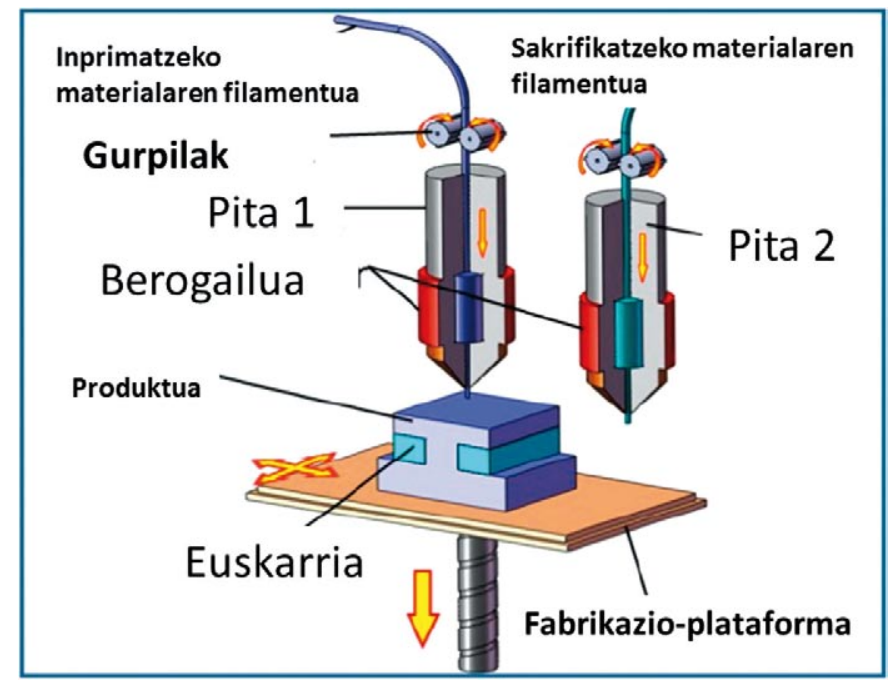

2. irudia. FDM teknologiaren irudikapen eskematikoa [9].

Teknika honen muga nagusia beharrezko materialaren kalitate altuan datza. Hots, tentsio eta konpresiopean landu eta urtuko den materialaren kalitatea 
altua izan behar da, bukaerako produktuaren egonkortasun mekaniko eta termikoak eraginik izan ez dezan. Aldiz, abantailen artean, prezio baxua, maneiatzeko erraztasuna eta inprimaketa-prozesuaren abiadura nabarmen ditzakegu.

\subsection{Estereolitografia (Stereolithography, SLA)}

Estereolitografia (SLA) fabrikazio gehigarrirako garatutako lehen tekniketako bat izan zen. Oinarrian, erretxina polimeriko bat (epoxi edo akrilikoak, normalean), argi ultramorearen bidez onduz bi dimentsiotan inprimatzen da fotopolimerizazio prozesuaren bitartez. 3. irudian azaltzen den bezala, txantiloi-lana betetzen duen plataforma polimero likidoz betetako kubeta batean murgiltzen da 0,05-0,15 mm bitarteko sakonerara. Argi ultramorea igortzen duen laserra ispilu baten bitartez polimeroa duen patroirantz islatzen da, eta geruzaz geruza objektua eratzen da txantiloiaren gainazalean.

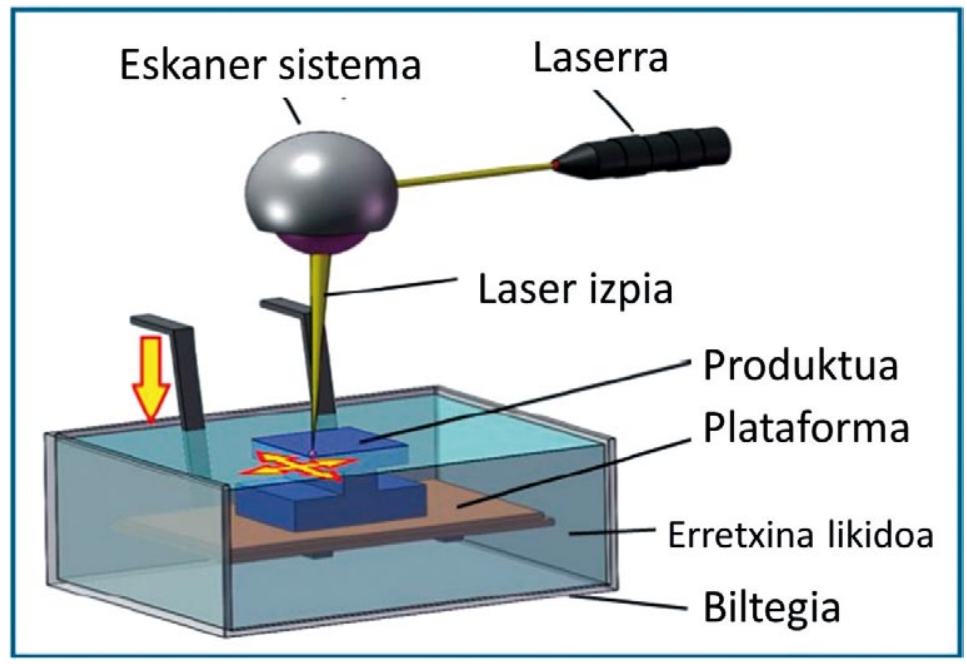

3. irudia. SLA teknologiaren irudikapen eskematikoa [9].

Polimerizazioaren sakonerak, laserraren potentziak eta argiztapen-abiadurak eta denborak amaierako produktuaren kalitatea definitzen dute. Zalantzarik gabe, prozesuaren abantaila nagusia haren abiadura altua eta erresoluzio bikaina dira. Hala ere, kostuak industria mailako eskalatzea mugatu du.

\subsection{Argiaren prozesatze digitala (Digital Light Processing, DLP)}

Argiaren prozesatze digitala (DLP), SLAren antzeko fotopolimerizazio-prozesua da. Kasu honetan, aldiz, 4. irudian ikusten den bezala, argia maskara digital batean proiektatzen da bi dimentsioko patroia lortzeko. 
SLAn bukaerako produktuaren erresoluzioa laser izpiaren tamainaren araberakoa bada ere, DLPn proiektatutako irudiaren pixelaren tamainaren menpekoa da. Teknikoki, DLPa SLAa baino azkarragoa da, baina lortzen den erresoluzioak eta gainazalaren kalitateak ez dute zerikusirik. Ondorioz, tamaina handiko objektu ugari inprimatzeko oso erabilgarria da.

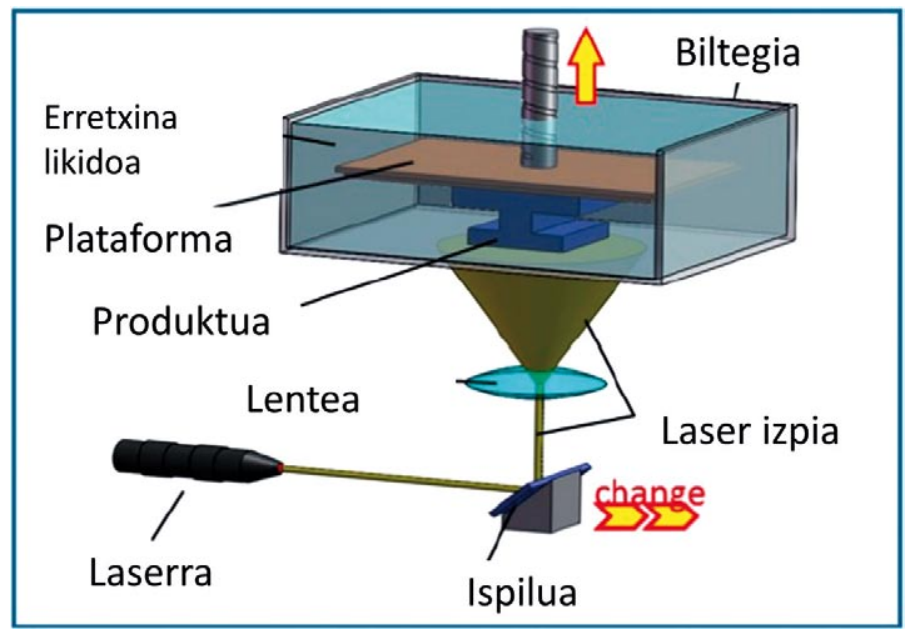

4. irudia. DLP teknologiaren irudikapen eskematikoa [9].

\subsection{Laser bidezko sinterizazio selektiboa (Selective Laser Sintering, SLS)}

Hauts-ohantzearen bidezko fusioaren adibide nagusia da laser bidezko sinterizazio selektiboa (SLS). 5. irudian ikusten den moduan, konfigurazioa bi ganbara nagusitan banatzen da: hautsa gordetzen duen ganbara eta inprimaketarako ganbara. Biak materialaren fusio-tenperaturaraino berotzen dira eta potentzia handiko laser-izpi batek hautsaren gainazala argitu ondoren, bi dimentsioko patroi baten gainean trinkotzen (sinterizatzen) da. Ganbaretako mugimendu bertikalek geruzaren lodiera definitzen dute. Trinkotutako materialaren gainean, arrabola baten bidez, hauts berria erortzen da, eta pausoz pauso hiru dimentsioko objektua sortzen da. Azken pausoan, kanpoko geruzako trinkotu gabeko hautsa garbitu behar da.

SLS inprimaketaren kalitatea definitzen duten faktore nagusiak honako hauek dira: hauts-partikulen tamaina, laserraren potentzia eta tamaina, eta haren abiadura. Abantailen artean, aurreko hiru teknologiekin alderatuta, aipatzekoa da konplexutasun handiagoko piezak inprimatzeko erraztasuna. Desabantailen artean, kostua nabarmen dezakegu (berogailuak, laserra, tresneria). Tradizionalki metalak inprimatzeko erabili izan bada ere, polikaprolaktonak edo poliamidak bezalako termoplastikoetarako erabil daiteke; izan ere, haren oztopo nagusia difusio molekularraren bidezko trinkotzea baita. 


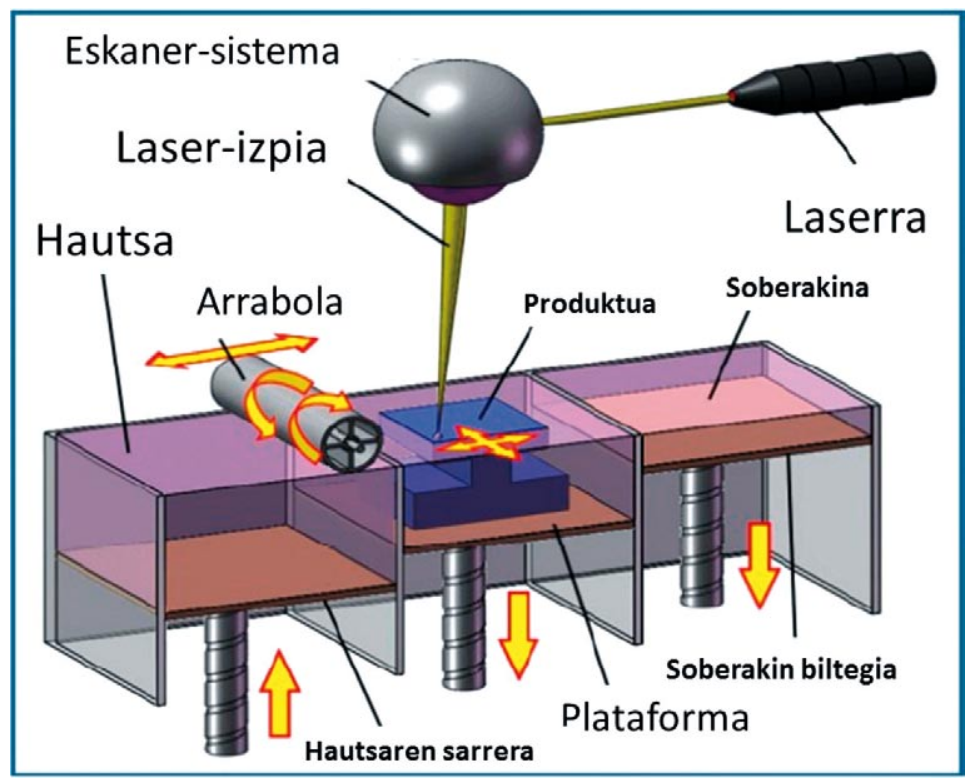

5. irudia. SLS teknologiaren irudikapen eskematikoa [9].

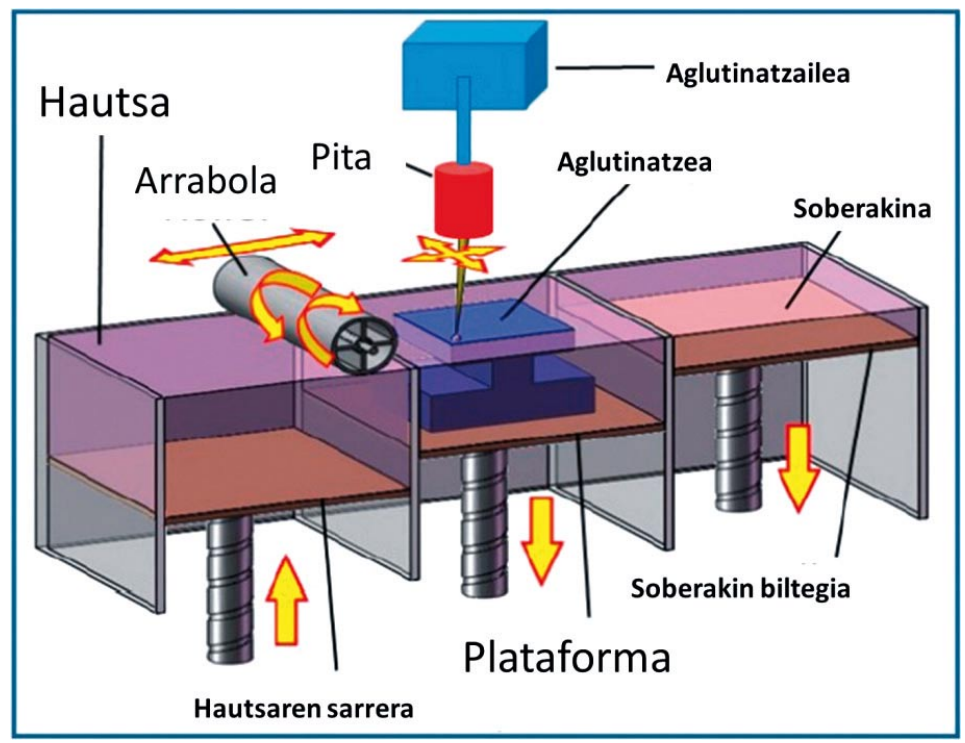

6. irudia. 3DP teknologiaren irudikapen eskematikoa [9]. 


\subsection{Hiru-dimentsioko inprimaketa (Three-Dimensional Printing, 3DP)}

Hiru-dimentsioko inprimaketa (3DP) MITek (Massachusettseko Teknologia Institutua) garatu zuen injekzio aglutinatzailean oinarritutako teknika da (6. irudia). Horretan, hautsaren eta aglutinatzaile baten arteko elkarrekintza erabiltzen da trinkotzea lortzeko; faktore garrantzitsuenak hautsaren partikulen tamaina eta aglutinatzailearen biskositatea dira. Teknologia honek, merkea izateaz gain, material ezberdinen erabilera ahalbidetzen du. Hala ere, bukaerako produktuaren kalitatea gainazalaren eta porositatearen aldetik, ez da oso ona izaten.

\subsection{Ijeztutako Objektuen Manufaktura (Laminated Object Manufacturing, LOM)}

Industrialki asko erabiltzen den teknika dugu Ijeztutako Objektuen Manufaktura (LOM). 7. irudian deskribatzen den bezala, inprimaketa energia termikoaren bidezko ijezketa da, non materiala laser bidez mozten den. Prozesu motela da eta erresoluzio aldetik nahiko mugatua; baina merkea denez, arrakasta handia du industria mailan.

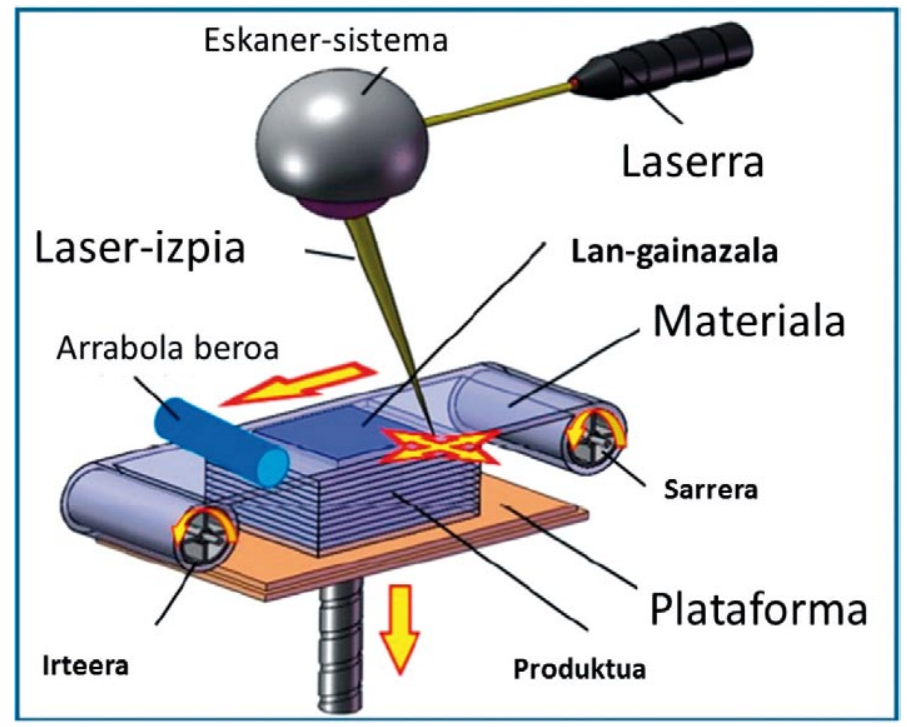

7. irudia. LOM teknologiaren irudikapen eskematikoa [9].

\subsection{PolyJet Teknologia}

Injekzio bidezko PolyJet teknologian, fotopolimero likido baten tantatxoak gehitzen dira substratu baten gainean (8. irudia). Argi ultramoreak 
erretxinaren ontzea eragiten du, eta material solidoren geruza fin-finak sortzen dira. Prozesu konplexu eta motela da, baina erresoluzio handiko piezak egin daitezke teknika honen bidez [10].

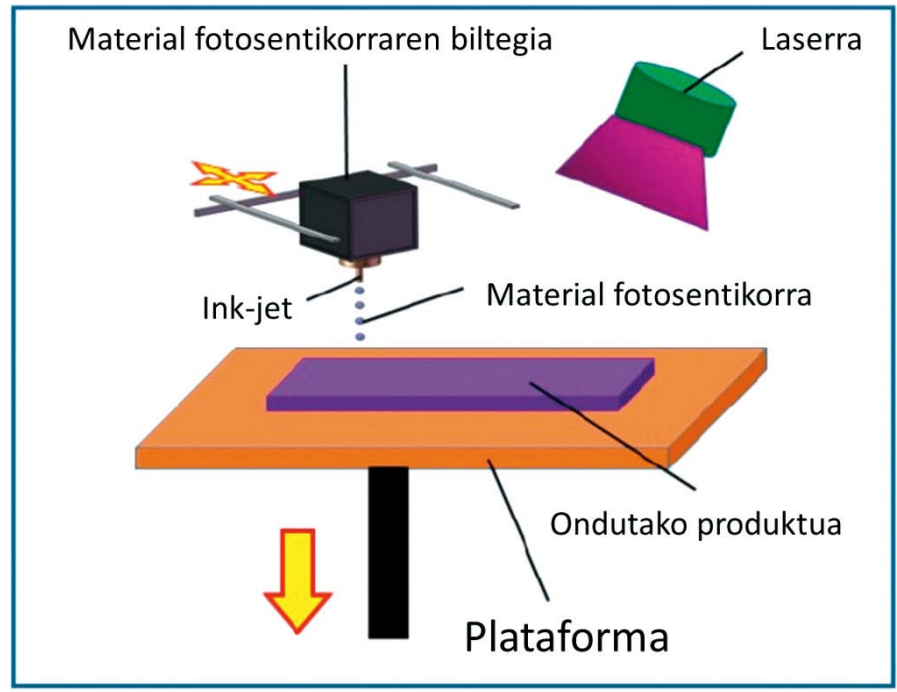

8. irudia. PolyJet teknologiaren irudikapen eskematikoa [9].

\section{FABRIKAZIO GEHIGARRIAN ERABILTZEN DIREN POLIMEROAK}

Aurretiaz aipatu den bezala, fabrikazio teknikaren arabera, polimero termoplastikoak (FDM, SLS, 3DP, LOM tekniketan) edo termoegonkorrak (SLA, DLP, PolyJet, tekniketan) erabiltzen dira. Lehenak egitura molekular lineala duten material gisa definitzen dira, eta gai dira beroaren edo presioaren bidez urtu edo biguntzeko. Bigarrenek elkargurutzaketa kimikoan oinarritutako egitura aurkezten dute, eta, ondorioz, deskonposatu egiten dira urtu edo bigundu beharrean [11].

\subsection{Polimero termoplastikoak}

Termoplastiko erabiliena akrilonitrilo-butadieno-estireno (ABS) kopolimeroa da (9. irudia). Ehunka kolore eta propietate mekaniko aurkez ditzaketen nahaste ezberdinak FDM metodoaren bidez lantzen dira. Guztiz amorfoak diren materialak ezin hobeak izan ohi dira FDMrako, ez baitute fusio puntu definiturik aurkezten, eta materialak, berotu ahala, gero eta gehiago biguntzen baitira. Polimeroaren biskositatea behar bezain altua 
izan behar da, estrusioaren forma mantendu eta azkar eta erraz solidotzeko. Bestalde, azido polilaktikoa (PLA) sarritan erabiltzen da ABSaren ordezko gisa. Bi material hauek prozesatzeko orduan, beharrezkoa da pieza euskarri baten erabilera (material arinagoz egina, hala nola, argizaria edo poli(binil) alkoholaz); pieza hori fabrikazio prozesuaren azken pausoan urtu edo disolbatuz ezabatuko da. Propietate mekaniko hobeak behar direnean, aldiz, material sofistikatuagoak erabil daitezke, hala nola polikarbonatoak, polieterimida (estandar industrialen artean ULTEM 9085 materiala oso ezaguna da) eta polietersulfonak. Azken hauek ordea gama altuko tresneriaz soilik landu daitezke [12].<smiles>C=CC=C</smiles>

1,3-Butadienoa

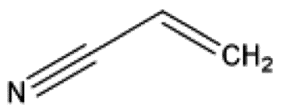

Akrilonitriloa

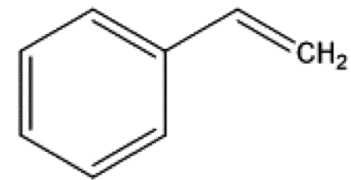

Estirenoa

9. irudia. ABS kopolimeroaren osagai diren monomeroen egitura molekularra.

SLSk termoplastiko kristalinoak erabiltzen ditu, polimeroaren urtzeprozesua azkarra eta bat-batekoa izan behar baita. Fusio-puntu baxuko termoplastiko kristalinoen (erdi-kristalinoen) artean poliamidak dira ohikoenak. Ezagunena Nylona (nylon 6,6) bada ere (10. irudia), merkatuan eskuragarri daude poliamida 11 eta poliamida 12 . Zenbakiek monomeroen karbono atomoen kopurua adierazten dute. Propietate mekanikoak hobetzeko asmoz, zenbait enpresak poliamidetan oinarritutako material konposatuak komertzializatu dituzte: adibidez, 3D Systems-en Duraform GF (beira partikulaz betetako poliamida 12) edo EOS GmbHren karbono zuntzez indarturiko konpositeak.

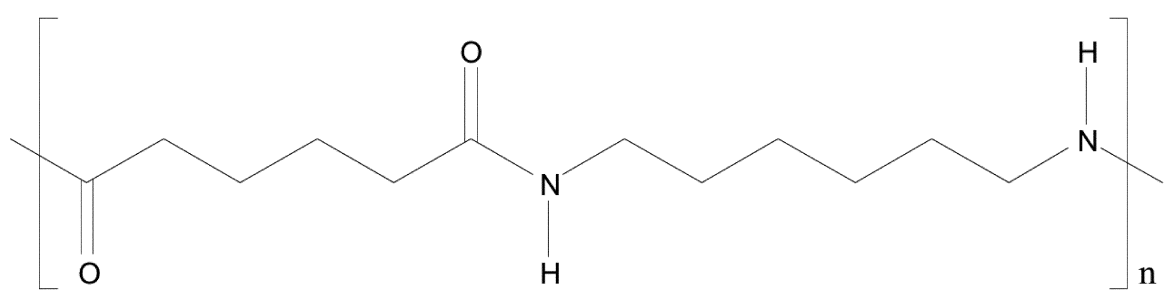

10. irudia. Nylon 6,6-aren egitura molekularra.

Bestalde, sarritan flexibilitate handiko elastomeroak erabil daitezke; egonkortasun termiko eta kimiko handia izateaz gain, kautxuaren antzeko propietateak erakusten dituzte. Nabarmentzekoak dira biomedikuntzan era- 
biltzen diren elastomero bio-bateragarriekin egindako lanak, besteak beste polikaprolaktona (PCL), azido polilaktikoa (PLA) eta bere bertsio kiralean, azido poli(L-laktikoa) (PLLA) oinarritutakoak.

Aglutinatzaile likidoekin batera gehitzen diren polimero-hautsak, poli(metilmetakrilato)etara (PMMA) mugatzen dira (11. irudia). Izan ere, 3DP teknika hauts zeramikoekin erabiltzen da gehienbat. Polimeroek metal aglutinatzailearen lana betetzen dute sarritan, baina komertzialak diren produktuen formulazioak ez daude eskuragarri. Azkenik, LOM teknologiari dagokionez, ekoitzi zen lehen materiala biltzeko papera izan zen, hau da, poli(binilkloruro)zko (PVC) geruza finez elkartutako papera. Egun, xaflatan egituratutako polimero/zeramiko eta polimero/metal sistemen ikerketan lan handia egiten ari da [12].
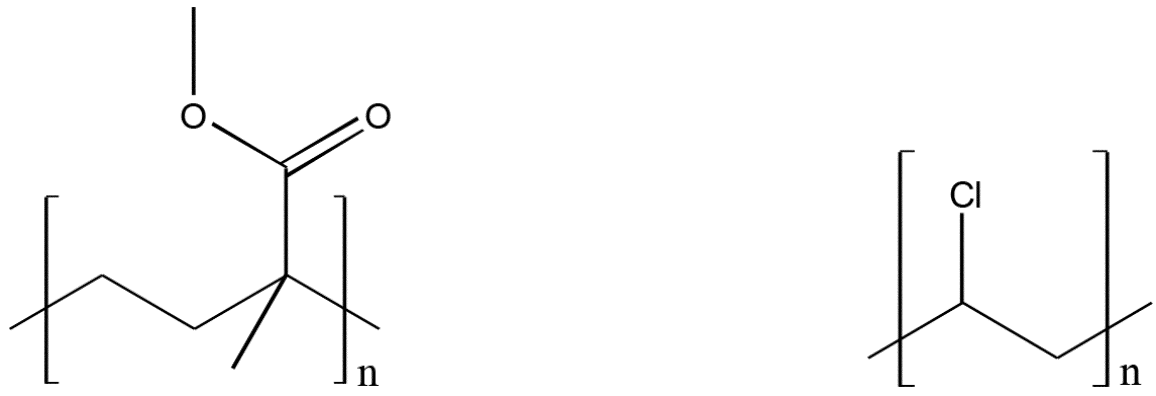

11. irudia. PMMA (ezkerra) eta PVC-aren (eskuina) egitura molekularrak.

\subsection{Polimero termoegonkorrak}

SLA, DLP eta PolyJet teknologietan, likido-egoeran dauden fotopolimero termoegonkorrak erabiltzen dira. Erradiazio ezberdinen aurrean (industrialki, argi ikusgaia edo ultramorea bakarrik erabiltzen dira) trinkotzen diren polimero hauei «erretxina» izena ematen zaie. Ohiko erretxinak monomero, oligomero, fotohasarazle, inhibitzaile, eta beste zenbait gehigarri ezberdinen (besteak beste, koloratzaileak, gogortzaileak, aparren kontrako produktuak) nahasketa konplexuak izan ohi dira.

Hasiera batean, akrilato edo binileter monomeroen (12. irudia) eta fotohasarazle ultramoreen arteko nahasketak ospetsu bilakatu baziren ere, denboraz, uzkurtze-prozesu larria jasaten zutela ikusi zen: bukaerako pieza erabat deformatzen zen. Era berean, atmosferako oxigenoak polimerizazio-erreakzioa inhibitzen zuela ikusita, erretxina hauen erabilera zertxobait baztertu zen. Nahiz eta polimerizazio-prozesu konplexuagoa jarraitu, desabantaila hauek gainditu nahian, epoxi erretxinak aukeratu ziren ordezko gisa. 

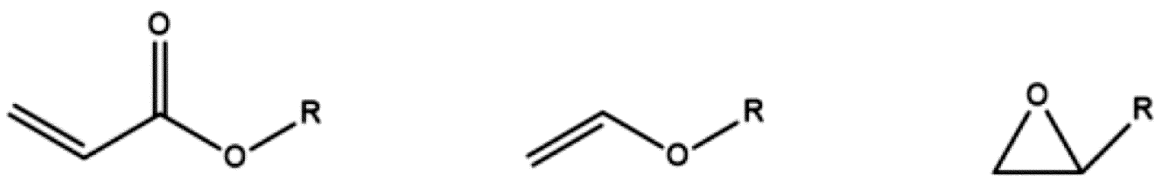

12. irudia. Ezkerretik eskuinera, akrilato, binil eter eta epoxi taldeen egitura molekularrak.

Gaur egungo erretxina komertzial gehientsuenak akrilato, epoxi eta beste material oligomeriko batzuen nahasteak dira. Akrilatoek azkar erreakzionatzen dute; epoxi taldeak, berriz, erresistentzia mekanikoaren erantzuleak dira. Monomero mota ezberdinek ez dute elkarrekin erreakzionatzen: akrilatoen kasuan polimerizazio erreakzio erradikalarioa den bitartean, epoxidoen kasuan kationikoa da. Hala ere, monomero bakoitzak bere aldetik eratzen dituen sare polimerikoak fisikoki elkargurutzatuta egoten dira, bukaerako produktuari propietate mekaniko egokiak emanez. Sare polimerikoak eratu ahal izateko, akrilato taldeek talde funtzional bat baino gehiago izaten dituzte. Ohikoak dira, besteak beste, poliester akrilatoak, akrilato epoxidikoak, uretano akrilatoak eta amino akrilatoak. Mekanismo erradikalarioaren hasarazle gisa, bentzoina, azetofenona, bentzilazetala edota ziklohexilfenil zetona erabiltzen dira. Epoxi taldeei dagokienez, arruntenak poliglizidilo eter eta esterrak izan ohi dira, eta erreakzio kationikoaren hasarazleak, onio edo metalozeno gatzak.

Injekzio bidezko teknologietan ere antzeko formulazioak erabiltzen dira, baina kasu hauetan, ezinbestekoa izaten da materialaren biskositatean arreta jartzea. Inguru-tenperaturan biskositate handia duten polimeroekin lan egiteko, injekzio-prozesuaren aurretik materiala berotzea izaten da irtenbidea. Gaur egun ordea, tenperatura igo behar ez izateko, erretxinaz, diluitzailez (biskositate baxuko materialak: esaterako, parafina) eta gehigarriz osatutako formulazioak saltzen ditu 3D System-ek.

\section{ERABILERAK}

Azken atal honetan, fabrikazio gehigarriaz prestatutako polimeroen erabilera nagusiak aipatuko dira. Nahiz eta aplikazio-eremu zabala aurkeztu (13. irudia), nabarmentzekoa da, bereziki, biomedikuntzan, elektronikan eta industria aeroespazialean duten garrantzia. Hala ere, orain arte, prototipoen garapenarekin erlazionatutako arloetan teknologia esanguratsu gisa agertzen den arren, fabrikazio gehigarriaz prestatzen diren objektuen $\% 29$ baino ez dira funtzionalak; hots, ez dute aplikazio praktikorik. Ondorioz, merkatuan prototipoen prestaketarako fotopolimeroak gailentzen dira (fabrikatzen diren piezen \% 50). Pieza funtzionalen artean, aipagarriak dira 
SLS bidez inprimatutako termoplastikoak (poliamidak, elastomero termoplastikoak ...), gehienbat industria aeroespazialean erabiltzen direnak [13].

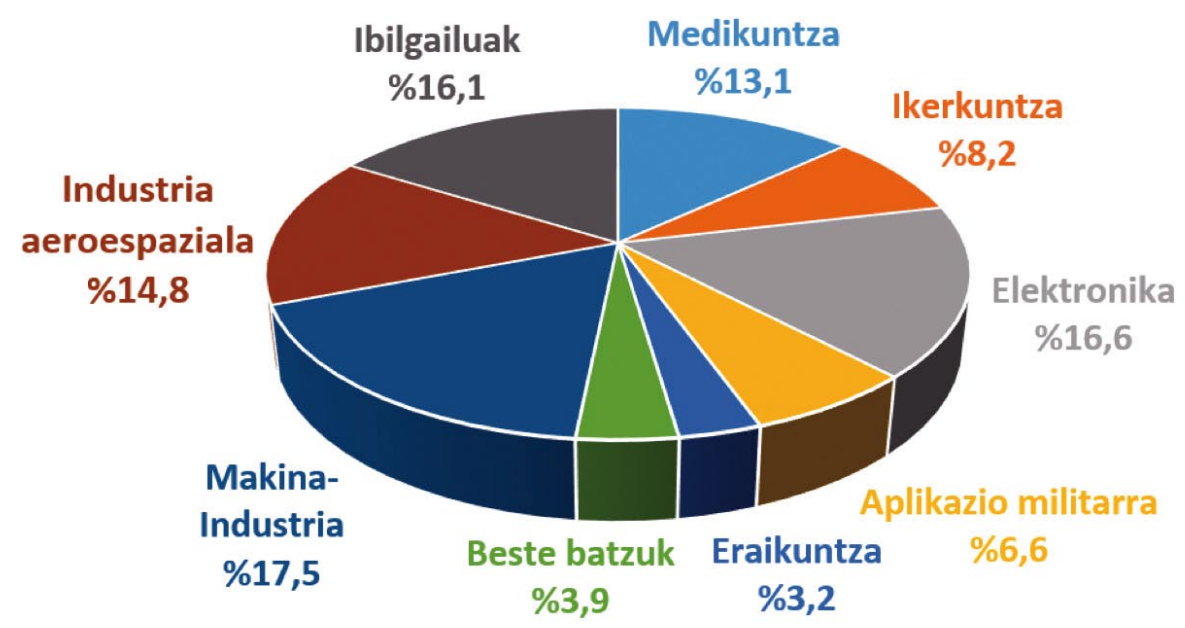

13. irudia. Polimeroetan oinarritutako fabrikazio gehigarriaren aplikazio-eremuak industria-sektorearen arabera.

\subsection{Biomedikuntza}

Biomedikuntzaren mundu zabalean, polimeroetan oinarritutako fabrikazio gehigarria inplanteak eta protesiak egiteko erabiltzen da, baina baita birsorkuntza medikuntzan eta ehunen ingeniaritzan ere [14-16]. Orokorrean, inprimagarritasuna, biobateragarritasuna eta propietate mekaniko aproposak aurkeztea izan ohi dira bete beharreko baldintzak. Polimero hauek jatorri naturala (gelatina, alginatoa, kolagenoa...) zein sintetikoak (polietilen glikola, PEG; poli(azido laktiko-ko-glikoliko)a, PLGA; poli(binil alkohol)a, PVA...) izan ditzakete.

Nahiz eta orain arte fotopolimeroak iraupen luzeko inplante kirurgikoetan erabili ez diren, aspaldidanik erabili izan dira hortzen zaharberritzean. Oso ezagunak dira txantxarrak betetzeko metakrilatoetan oinarritutako erretxinak, bracket metalikoen ordezkoak eraikitzeko ere aplika daitezkeenak. Oro har, pieza guzti hauek SLA teknikaren bidez inprimatzen dira. Bestalde, audifono pertsonalizatuen diseinuan paper garrantzitsua jokatzen dute polimeroek, gaixoaren belarria eskaneatu eta momentuan bertan inprimatu baitaiteke dispositiboa. Prozedura berari jarraitzen zaio tomografia edota erresonantzia magnetiko nuklearraren bidez jasotako organoen edo ehunen hiru-dimentsioko irudiak inprimatzeko orduan [17]. Metodo hau belaun-, garezur-, aldaka- edo sorbalda-inplanteetan erabili da, eta baita bihotzeko balbula berriak fabrikatzeko ere. Adibide ikusgarri gisa, bihotz 
osoaren eredu malgu eta gardenak eraiki ahal izan dira, eta baita guztiz funtzionala zen giltzurruna sortu ere 2002an [18].

1. pausoa: Masailezurreko arazoa

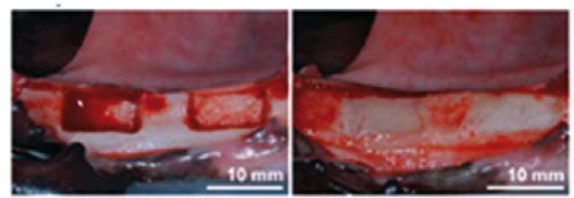

3. pausoa: Materialaren fabrikazioa

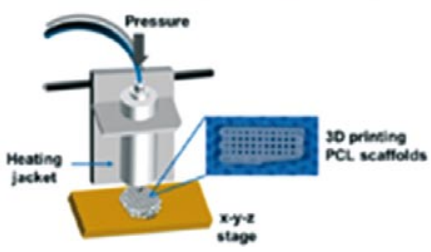

2. pausoa: Eredu digitalaren diseinua

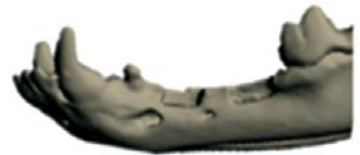

4. pausoa: kirurgia

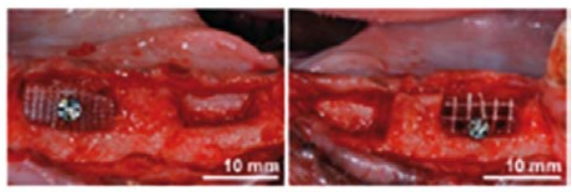

14. irudia. Masailezurreko lesio baten aurrean 3D inprimaketa bidez egindako scaffoldaren adibide eskematikoa. Pausoak: arazoa, diseinua, fabrikazioa eta inplementazioa [19].

Ehunen ingeniaritzan eta medikuntza birsortzailean, aldamio edo «scaffold»-ak funtsezkoa dira zelulen infiltrazio eta ugalketarako konexio fisikoa eskaintzeko (14. irudia). Fabrikazio gehigarriaren bitartez, forma eta porositate kontrolatuak dituzten piezak lor daitezke, eta, era berean, inprimatutako scaffoldaren barnean bioaktiboak diren partikulak garraiatu. Arruntak dira SLS bidezko polikaprolaktonak (PCL) eta PolyJet bidezko poliazido laktikozko (PLA) pieza biodegradagarriak edota hezur sintetiko (hidroxiapatita) / PLGA konpositeak. Horretaz gain, FDM bidezko metakrilatoak inplanteak eta inguruneko ehunak elkartzeko «torloju» gisa diseinatu dira [19].

\subsection{Elektronika}

Elektronikaren arloan duen ekarpena momentuz haren hastapenetan badago ere, eroale elektrikoak polimeroekin konbinatuz sortutako konpositeak sentsore elektrikoak garatzeko erabili dira [20,21]. Horrela, sentsore piezorresistiboak eta sentsore kapazitiboak sortu dira PCL eta karbono deribatuak erabiliz (15. irudia). Sentsore piezorresistiboek tolestura mekanikoa, erresistentzia elektrikoaren aldaketen bidez detekta dezakete. Kapazitiboak, aldiz, beste gailu batzuen barruan txertatuta egoteko inprima daitezke: adibidez, uraren presentzia eta gabezia detektatzeko [22]. 

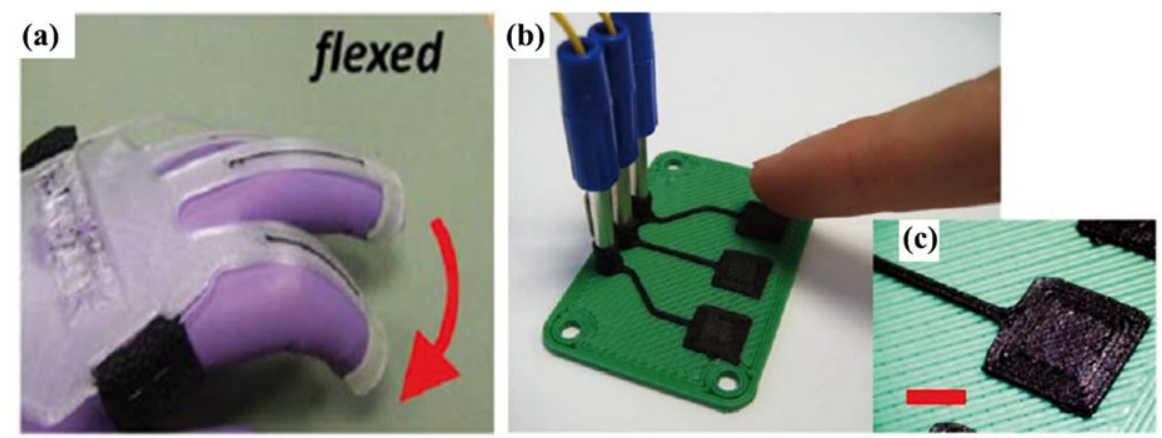

15. irudia. Fabrikazio gehigarri bidez sortutako sentsore piezorresistiboa (a), kapazitiboa (b) eta mikroelektronika-zirkuitua (c) (eskala-barra 5 mm-koa da) [22].

a)

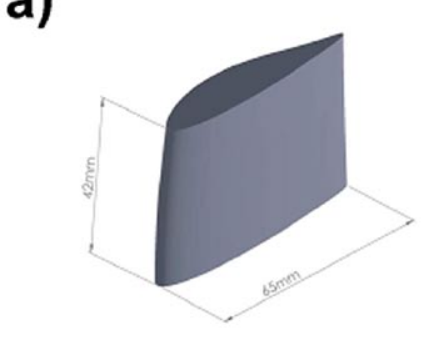

b)

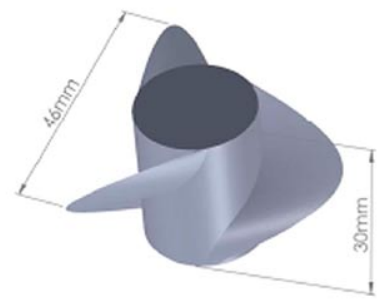

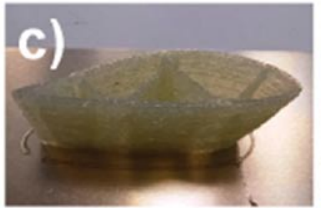
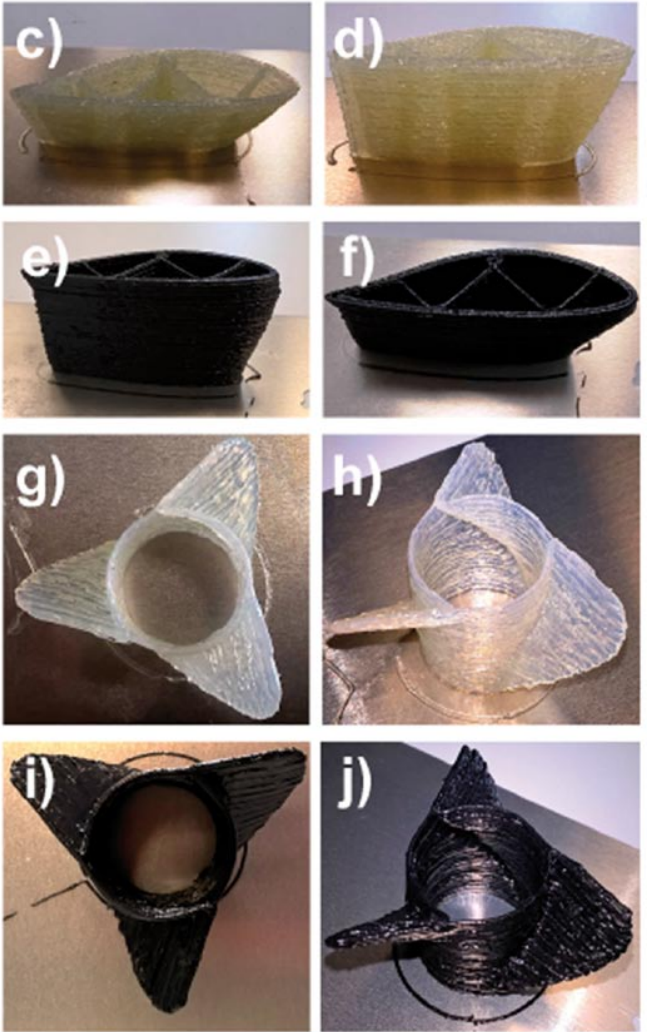

16. irudia. Gainazal aerodinamikoaren (a) eta helizearen (b) hiru dimentsioko ereduak. Fotopolimerizazio bidez inprimatutako beira-zuntzezko (c, d, g, h) eta karbono-zuntzezko (e, f, i, j) konpositeak [24]. 


\subsection{Industria aeroespaziala}

Industria aeroespazialeko pieza gehienek geometria konplexuak azaltzen dituzte, fabrikazio-prozesu garesti eta luzeak eskatzen dituztenak. Zentzu honetan, fabrikazio gehigarria alternatiba baliagarri gisa agertzen da. Motorraren ihes-hodia eta turbinaren piezak ekoizteko, normalean material metaliko ezberdinen 3D inprimaketa erabiltzen da, polimeroek baino erresistentzia mekaniko eta termiko handiagoa agertzen dutelako [23]. Hala ere, oraintsu frogatu da aluminioa baino arinagoa den (masaren murrizketa $\% 50$ ingurukoa da) beira- eta karbono-zuntzez gogortutako fotopolimero (ULTEM 1000) konposite batek, metalek adinako erresistentzia mekanikoa (aluminioaren erresistentziaren $2 / 3)$ eta tenperatura «altuak» $\left(250^{\circ} \mathrm{C}\right)$ jasan ditzakeela (16. irudia) [24].

\section{ONDORIOAK}

Fabrikazio gehigarriak eta 3D inprimaketak gure etorkizuna aldatuko dutela uste da. Edozein ordenagailutan edonork objektu bat diseinatu eta munduko beste edozein puntutan momentuan bertan inprimatzeko aukera (adibidez, zure etxean bertan!) etorkizunean, ametsa izatetik errealitate izatera pasa daiteke. Lan-esparruak ez du mugarik: biomedikuntzatik hasi (protesiak, scaffold-ak) eta industria teknologiko modernoenera (elektronika, aeroespaziala), edo, zergatik ez, norbere gustuko denborapasetara (arropak, bitxigintza, sukaldaritza, arte lanak, jostailuak...) baitoa. Prozesuen kostuek behera egiten duten heinean, teknologia askoz eskuragarriagoa bihurtuko da. Beraz, badakizue: inprima dezagun gure etorkizuna!

\section{ESKER ONAK}

Egileek UPV/EHU (PPG17/37, GIU17/050) eta Eusko Jaurlaritzako Hezkuntza Sailetik (IT718-13) jasotako diru-laguntza eskertzen dute. C.M.ek BCMaterials fundaziotik jasotako doktorego aurreko kontratua eskertzen du.

\section{BIBLIOGRAFIA}

[1] Bandyopadhyay, A., Bose, S. 2015. Additive Manufacturing. CRC Press, Massachusetts, USA.

[2] Eyers, D. R., Potter, A. T. 2017. «Industrial Additive Manufacturing: A manufacturing systems perspective». Computers in Industry, 92-93, 208218. 
[3] Ngo, T. D., Kashani, A., Imbalzano, G., Nguyen, K. T. Q., Hui, D. 2018. «Additive manufacturing (3D printing): A review of materials, methods, applications and challenges». Composites Part B: Engineering, 143, 172-196.

[4] https://www.iso.org/news/2015/05/Ref1956.html (2018-07-24)

[5] De Leon, A. C., Chen, Q., Palaganas, N. B., Palaganas, J. O., Manapat, J., AdVINCUlA, R. C. 2016. «High performance polymer nanocomposites for additive manufacturing applications». Reactive and Functional Polymers, 103, 141-155.

[6] Bourell, D., Kruth, J. P., Leu, M., Levy, G., Rosen, D., Beese, A. M., Clare, A. 2017. «Materials for additive manufacturing». CIRP Annals Manufacturing Technology, 66, 659-681.

[7] ISO / ASTM52900-15. 2015. Standard terminology for additive manufacturing - general principles - terminology. AST international, West Conshohocken PA, USA

[8] LeE, J. Y., AN, J., ChuA, C. K. 2017. «Fundamentals and applications of 3D printing for novel materials». Applied Materials Today, 7, 120-133.

[9] Xu, Y., Wu, X., Guo, X., Kong, B., Zhang, M., Qian, X., Mi, S., Sun, W. 2017. «The Boom in 3D-Printed Sensor Technology». Sensors, 17,1166 .

[10] Dizon, J. R. C., Espera, A. H., Chen, Q., Advincula, R. C. 2018. «Mechanical characterization of 3D-printed polymers». Additive Manufacturing, 20, 44-67.

[11] Charles E. Carraher, J. 2011. Polymer Chemistry. CRC Press, Massachusetts, USA.

[12] Gibson, I., Rosen, D., Stucker, B. 2014. Additive Manufacturing Technologies. 3D Printing, Rapid Prototyping, and Direct Digital Manufacturing. Springer, New York, USA.

[13] Ligon, S. C., Liska, R., Stampfl, J., Gurr, M., Mülhaupt, R. 2017. «Polymers for 3D Printing and Customized Additive Manufacturing». Chemical Reviews, 117, 10212-10290.

[14] Mironov, V., Boland, T., Trusk, T., Forgacs, G., Markwald, R. R. 2003. «Organ printing: Computer-aided jet-based 3D tissue engineering». Trends in Biotechnology, 21, 157-161.

[15] Seitz, H., Rieder, W., Irsen, S., Leukers, B., Tille, C. 2005. «Three-dimensional printing of porous ceramic scaffolds for bone tissue engineering». Journal of Biomedical Materials Research - Part B Applied Biomaterials, 74, 782-788.

[16] Melchels, F. P. W., Domingos, M. A. N., Klein, T. J., Malda, J., BarTOLO, P. J., HutmaCHER, D. W. 2012. «Additive manufacturing of tissues and organs». Progress in Polymer Science, 37, 1079-1104.

[17] Landers, R., Mülhaupt, R. 2000. «Desktop manufacturing of complex objects, prototypes and biomedical scaffolds by means of computer-assisted design combined with computer-guided 3D plotting of polymers and reactive oligomers». Macromolecular Materials and Engineering, 282, 17-21. 
[18] Wang, X., JiAng, M., Zhou, Z., Gou, J., Hui, D. 2017. «3D printing of polymer matrix composites: A review and prospective». Composites Part B: Engineering, 110, 442-458.

[19] Park, S. A., Lee, H. J., Kim, K. S., Lee, S. J., Lee, J. T., Kim, S. Y., Chang, N. H., PARK, S. Y. 2018. «In vivo evaluation of 3D-printed polycaprolactone scaffold implantation combined with $\beta$-TCP powder for alveolar bone augmentation in a beagle defect model». Materials, 11, 238.

[20] Espalin, D., Muse, D. W., MacDonald, E., Wicker, R. B. 2014. «3D Printing multifunctionality: Structures with electronics». International Journal of Advanced Manufacturing Technology, 72, 963-978.

[21] Lopes, A.J., MACDonALD, E., WiCKER, R. B. 2012. «Integrating stereolithography and direct print technologies for 3D structural electronics fabrication». Rapid Prototyping Journal, 18, 129-143.

[22] Leigh, S. J., Bradley, R. J., Purssell, C. P., Billson, D. R., Hutchins, D. A. 2012. «A Simple, Low-Cost Conductive Composite Material for 3D Printing of Electronic Sensors». PLoS ONE, 7, 1-6.

[23] Liu, R., WANG, Z., Sparks, T., Liou, F., NewkiRk, J. 2016. «Laser Additive Manufacturing materials, design, technologies and applications». Elsevier Ltd. Missuri.USA

[24] Invernizzi, M., Natale, G., Levi, M., Turri, S., Griffini, G. 2016. «UVassisted 3D printing of glass and carbon fiber-reinforced dual-cure polymer composites». Materials, 9, 583. 